\title{
Sustainable growth of Indian coal industry: policy perspectives and recommendations
}

Coal is the most abundant fossil fuel resource in India, and the country's industrial and economic heritage has been built upon indigenous coal. India is the world's $3^{\text {rd }}$ largest energy consumer after China and USA. However, as the country goes through profound economic and societal transformations, such as economic and population growth, urbanization and industrialization, energy demand is expected to increase substantially. Looking into the significance of coal not only in the energy-mix but also in the economic development of India, the paper is aimed at an assessment of coal sector in India which shall also help contextualize the place of coal in India's contemporary energy, industrial and social sectors amidst a range of developments - both national and international - related to coal sector. The authors looked into various aspects of Indian coal sector from a policy perspective and suggested subsequent course of action so the same can be used by Indian coal mining stakeholders towards the larger goal of sustainable growth of coal sector including coal mining. The analysis produced important policy recommendations for coal industry stakeholders including the Indian Government, who is the sovereign owner of coal mine acreage in India.

Keywords: Coal; dry fuel; coal mining; coal regulations; sustainable growth; decarbonization; tndustry 4.0

\subsection{Introduction}

$\mathrm{C}$ oal is the most abundant fossil fuel resource in India, and the country's industrial and economic heritage has been built upon indigenous coal. In 2017 coal accounted for $44 \%$ of the total primary energy supply (TPES) [1] and $74 \%$ of electricity generation of the country's energy need [2]. However with high ash content and low calorific value, Indian coal is generally considered to be of sub-

Blind peer reviews carried out

Prof. Pramod Paliwal, Professor, School of Petroleum Management, Pandit Deendayal Petroleum University, Gandhi Nagar, Gujarat (India), E-mail: pramod.paliwal@spm.pdpu.ac.in / paliwalpo8@gmail.com Mr. Abhinav Sengupta, Senior Associate; Advisory, PwC India, E-mail: abhinavsengupta85@gmail.com and Ms. Neha Dixit, Assistant Professor, Department of Law, University of Rajasthan, E-mail: jdneha@yahoo.com standard quality. India is endowed with a vast $(\sim 326.50$ billion tonnes estimated as on 01.04.2019) of geological resources of coal and out of which $\sim 155.61$ billion tonnes (approximately $47.6 \%$ ) falls under the proven reserve category [3]. India is the 2 nd largest coal producer country in the world with $90 \%$ of coal coming from public sector companies - Coal India Limited (CIL) and the Singreni Collieries Co. Limited (SCCL). Remaining $10 \%$ is on account of captive and private miners. Hard coal deposits spread over 27 major coalfields, are mainly confined to eastern and south-central parts of the country.

The share of coal as total primary energy supply over last 3 decades 1990-1999, 2000-2009, 2010-2019 has increased at a CAGR of 5.48\% [4]. Contribution of coal in India's total electricity generation has been significant over last 3 decades (Fig.2). With the advent of liberalization in coal and power sector in 1991; the coal mining activity has witnessed $\sim 6$ folds increase in its contribution and dominated the India's energy sector subsequently. Thus coal is poised to play a predominant role in India's electricity generation in the coming years.

Indian coal mining sector has witnessed significant changes over past 4-5 decades. Table 1 provides a summary of these changes.

India, during year 2019-20 imported $\sim 249 \mathrm{Mt}$ of coal ( $\sim 54$ Mt of coking coal and $\sim 195 \mathrm{Mt}$ of non-coking coal) [10]. There is an immediate requirement by the Indian coal industry to substitute the imported thermal coal (i.e. non-coking coal) with domestic supply only which aims to reduce the dependence of dry fuel through imports and thus has the potential to reduce the import bill in tune of $\sim 6$ to $\sim 8$ billion dollars [11]. Government of India has initiated a policy towards creating Atmanirbhar Bharat (self-reliant India) [12] through opening up of commercial coal mining in order to boost Indian coal sector also subsequently announced a liberalized taxation structure for Indian power sector [13].

\subsection{Indian coal sector: significance for the economy}

India is the world's 3rd largest energy consumer after China and USA [14]. However, as the country goes through profound economic and societal transformations, such as economic and population growth, urbanization and 


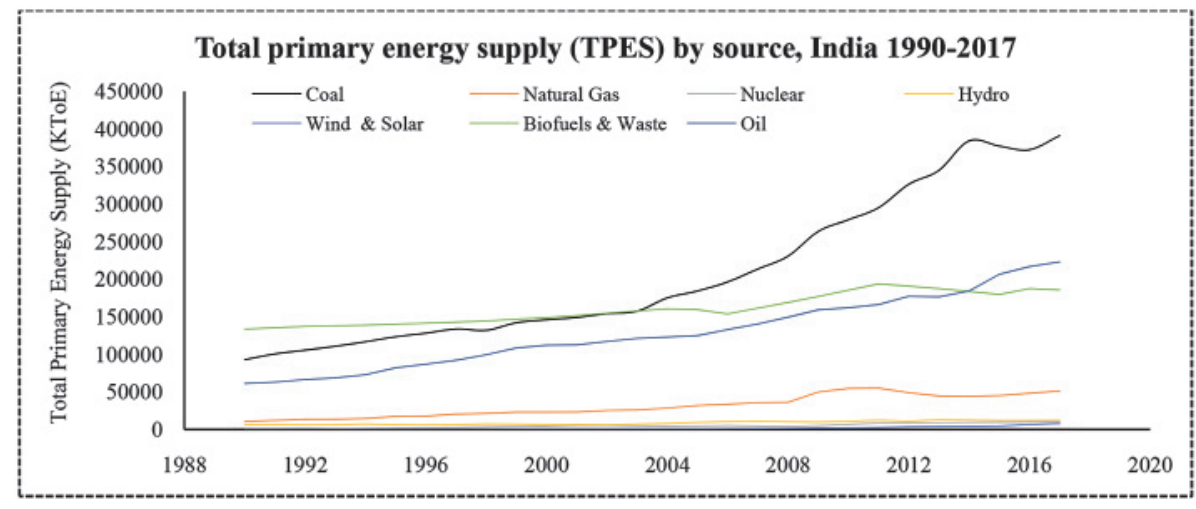

Source: IEA; World Energy Balances 2019, www.iea.org/statistics/.

Fig.1 Total primary energy supply by sources, India 1990-2017

India's Electricity Generation by coal as a Source of Energy (in GWh)

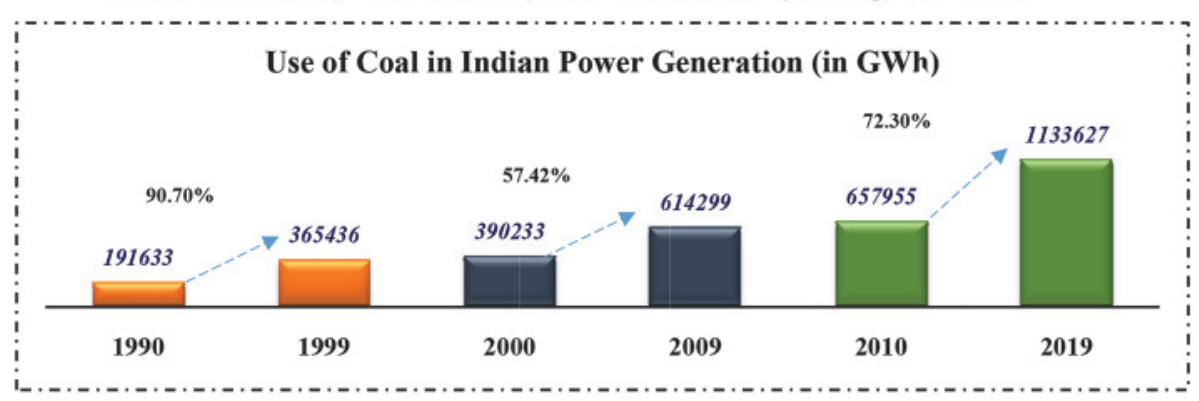

Source: IEA; World Energy Balances 2019, www.iea.org/statistics/.

Fig.2: Role of coal in electricity generation in India over the decades

TABLE 1: EVOLUTION OF INDIAN COAL MINING SECTOR

Year Indian coal mining sector: evolution over the years

1975 Nationalization of Indian coal industry - Public sector company, Coal India Limited (CIL) was formulated as a monopoly to market coal in India.

1993 Liberalization of Indian coal industry by allocation of captive blocks for power, iron and steel and subsequently for coal gasification and liquefaction.

2003 Power sector reformed - Electricity Act $2003^{5}$ that allowed private sector participation in electricity generation, triggered coal demand to rise rapidly for power sector.

2014 Supreme Court of India cancelled the allotment of 204 coal blocks from 1993 creating a huge demandsupply gap.

2015 Coal Mine Special Provision Act $2015^{7}$ and Mines and Minerals(Development and Regulation) Act 2015 (MMDR) came into existence and auctioning of coal blocks got commenced. ${ }^{8}$

2020 Commercialization of coal blocks commenced to create complete freedom towards accessing the dry fuel with Mineral Amendment Act 2020 industrialization, energy demand is expected to increase substantially. Coal is the one of the major commodities for development and growth of entire Indian economy (Table 2).

Since Indian independence in 1947, coal has been affecting all the segments of Indian society from being used as charcoal for domestic rural cooking to running ultra-mega thermal power plants (UMPP). Importance of the coal sector can be estimated from its position as one of the 8 core industries contributing to India's growth apart from cement, steel, natural gas, refinery products, crude oil, fertilizers and electricity with more than $(\sim 10.334 \%)$ of weight assigned to it [15] India is bestowed with huge reserves and is prima-facie a coal based economy.

Despite coal is being the largest energy source in India's primary energy mix, very few academic studies have been carried out on the economic managerial, policy and productivity aspects of the sector (Lahiri-Dutt, 2007; Sharma, 2012; Bhatnagar, 2014; Kulshreshtha and Parikh, 2001; Ioan et al, 2019; Carl, 2015). Similarly some studies have been carried out in the context of coal's role in thermal power generation in India and the consequences (Tongia and Gross, 2019; OCE, 2019; UP Gupta and Singh, 2017; Spencer et al, 2018; Woods and David, 2019). Carbon emissions have always been discussed in the context of entire coal value chain including mining. However it is encouraging to note that quite a few studies also discuss about looking for solutions to the emissions problems including some studies focusing on decarbonizing coal (O'Brien et al, 2020; Dermot and Younger, 2010; John et al, 2015; Konstantin et al, 2017. Kirk and Jessie, 2018; Pavloudakis et al, 2019; Lindsay et al, 2020; Tongia, 2020). Sustainable coal mining complements the goal of decarbonizing coal and subsequently tackling the carbon footprint issues associated with the coal value chain. Studies have discussed the aspect of making coal mining sustainable (Evans et al, 2003; Qian, 2010; Dorota et al, 2014; Huang et al, 2017; Lahiry, 2017; UNDP and UN Environment, 2018; Yu et al, 2020; Chattopadhyay and Chattopadhyay, 2020). In an era of heightened environmental and sustainability consciousness, the coal industry has no option but to adhere to tenets of sustainability. It has to keep evolving and take advantage of modern technology including the versatile 
TABLE 2: COAL SECTOR's ROLE IN INDIAN ECONOMY

\begin{tabular}{|c|c|}
\hline Contribution to sovereign wealth & Coal powered fuel economy \\
\hline $\begin{array}{l}\text { Coal is a major mineral in India and comes under the jurisdiction of the } \\
\text { central government. Apart from corporate taxes on coal projects, the } \\
\text { government also charges the following taxes: } \\
\text { a) Royalty at } 14 \% \text { on run-of-mine selling price } \\
\text { b) DMF at } 10 \% \text { of royalty } \\
\text { c) NMET at } 2 \% \text { of royalty } \\
\text { d) GST compensation cess @ INR } 400 \text { (USD 5.34) per metric tonne } \\
\text { e) State specific Environmental \& Development Taxes } \\
\text { Note: Total coal production in India during year } 2019-20 \text { was about } 729 \\
\text { million tonne and the total tax collection to the government was in the } \\
\text { range of INR } 40,000-45,000 \text { Crores (534-600 million USD) }\end{array}$ & $\begin{array}{l}\text { Coal has been the primary source of energy across } \\
\text { energy, manufacturing and industrial sectors. About } \\
54 \% \text { power generation capacity of India is coal } \\
\text { dependent. Besides powering the Indian thermal } \\
\text { power plants, coal is also consumed by steel, } \\
\text { sponge-iron, cement and paper industry. India has } \\
\text { more than } 400 \text { operational coal mines. Public Sector } \\
\text { coal companies account for } 90 \% \text { coal production in } \\
\text { India. Almost } 94 \% \text { of coal production comes through } \\
\text { open pit mining and balance through underground } \\
\text { coal mining. }\end{array}$ \\
\hline Abundant resource & Employment generation \\
\hline $\begin{array}{l}\text { Coal is a sedimentary flatbed deposit and is considered as a bulk } \\
\text { mineral. India has huge coal reserves of } \sim 320 \text { billion tonne and is } \\
\text { undergoing continuous exploration activity by government agencies like } \\
\text { GSI, MECL and CMPDI. } \\
\text { The average coal grade in India ranges between } 3800 \mathrm{Kcal} / \mathrm{kg} \text { to } 5500 \\
\text { Kcal/kg with high ash content i.e. from } 34 \% \text { to } 55 \% \text { spreading across } 27 \\
\text { coalfields. Coal production in India is concentrated in four states - } \\
\text { Odisha, Chhattisgarh, Jharkhand and Madhya Pradesh - which account } \\
\text { for almost } 80 \% \text { of production. Other producing states are Telangana, } \\
\text { Maharashtra and West Bengal, with smaller volumes produced also in } \\
\text { Uttar Pradesh, Meghalaya and Assam. Jharkhand is the largest producer } \\
\text { of coking coal. }\end{array}$ & $\begin{array}{l}\text { Indian coal mining supports direct employment of } \\
\text { around } \sim 5 \text { lakh workers. Considering direct and } \\
\text { indirect employment, several million jobs depend } \\
\text { upon development on the coal industry. CIL is one } \\
\text { of the 3rd largest public sector employer after Indian } \\
\text { Army and Indian Railways. Indian coal market } \\
\text { generates employment to the rural people across the } \\
\text { geographies. Government of India in order to pursue } \\
\text { the goal of Atmanirbhar Bharat (self-reliant India) in } \\
\text { coal sector is envisaging employment of } \sim 100 \\
\text { Thousand workers directly and indirectly through } \\
\text { commercial coal mining. }\end{array}$ \\
\hline
\end{tabular}

Source: Ministry of Commerce and Industry (https://commerce.gov.in/); Ministry of Coal (https://coal.nic.in/)

CIL: Coal India Limited; SCCL: Singreni Collieries Company Limited; MECL: Mineral Exploration Company Limited; CMPDI: Central Mine Planning \& Development Institute; GSI: Geological Survey of India; DMF: District Mineral Foundation; NMET: National Mineral Exploration Trust; GST: Goods and Service Tax

digital technologies. Coal mining, a hardcore extraction activity, has not been untouched with the Industry 4.0 wave. Rather it is interesting to see that the coal mining industry stakeholders have been quite proactive in reaping the benefits of Industry 4.0 and digitalization to bring about operational efficiencies in the mining activities (Sean, 2017; Zhou et al, 2017; Bertayeva et al, 2019; Alasdair, 2018; Benton, 2019; Mining Review Africa, 2019. Dorota and Tamer, 2019; Sarah, 2019). Moreover the industry is also learning from best examples of application of Industry 4.0 in other extractive sector mining activities (Hugh et al, 2015).

Authors, have relied on certain energy sector policy studies by experts (Frewer et al, 2011; Katz et al 2011; IAEA, 1998; Vrkljan et al 2017; Antwi et al, 2017; Banda and Kumarasamy, 2020) to deal with the question: "How to ensure sustainable growth for Indian coal industry through appropriate policy measures.

The analysis of Indian coal sector has been focused at:

1. Ascertaining key policy challenges for India's coal industry and suggesting appropriate recommendations to tackling them.

2. (a) Identifying measures to making Indian coal industry sustainable for upcoming decades

(b) Role of Industry 4.0 in making Indian coal industry sustainable

\subsection{Ascertaining key policy challenges for India's coal industry and suggesting appropriate recommendations to tackling them}

With decades of evolution of Indian coal sector from liberalization to commercialization; it still has many loose ends that needs to be tightened before creating a proper investment allowance regime for the most trusted source of fuel for Indian industries. Explained in Table 3 the few of critical issues as deciphered by the authors for the immediate attention of concerned Indian coal sector stakeholders:

\subsection{Identifying ways to making coal sustainable for upcoming decades}

The intrinsic nature of the dry fuel coal, which produces huge amount of calorific energy (ranges $2500 \mathrm{kcal} / \mathrm{kg}$ to $7000 \mathrm{kcal} /$ 
TABLE 3

\begin{tabular}{|c|c|c|}
\hline Challenges & Key concerns & Recommended actions \\
\hline $\begin{array}{l}\text { 1. Obtaining } \\
\text { clearance and land } \\
\text { acquisition and } \\
\text { relief and } \\
\text { rehabilitation } \\
\text { (R\&R) }\end{array}$ & $\begin{array}{l}\text { a) To make a greenfield coal mining project } \\
\text { operational around } \sim 20 \text { number of clearances } \\
\text { from respective central and state governments } \\
\text { agencies are required, which restricts ease of } \\
\text { doing business. } \\
\text { b) Significant delays occur due to multiple } \\
\text { layers for providing clearances. Delays also } \\
\text { happen due to archaic model of functioning, } \\
\text { bureaucratic hurdles, corruption, and non- } \\
\text { alignment to central government goals. Project } \\
\text { economics suffers heavily due to these delays } \\
\text { in obtaining clearances. } \\
\text { c) Land acquisition along with R\&R (Relief \& } \\
\text { Rehabilitation) of project affected people } \\
\text { (PAP) is another pain- point for the coal } \\
\text { mining players. The challenges are in } \\
\text { mapping the details \& family tree of the land } \\
\text { owners for their respective lands, getting } \\
\text { consensus of PAPs through public hearing, } \\
\text { evaluating the land compensation amount } \\
\text { according to LARR } 2013 \text { Act }{ }^{1} \text {, identification } \\
\text { of alternative land for PAPs and their } \\
\text { relocation and finally obtaining the physical } \\
\text { possession of land. } \\
\text { d) In case of forest land to be acquired the } \\
\text { challenges are identification and purchase of } \\
\text { CA(Compensatory afforestation) land and } \\
\text { afforestation process in CA land. }\end{array}$ & $\begin{array}{l}\text { 1) Government has appointed a PMU } \\
\text { (Project Management Unit) to handhold } \\
\text { the mining players to obtain the } \\
\text { clearances. The PMU must ensure } \\
\text { transparent and time bound milestones } \\
\text { required to be achieved with proper } \\
\text { tracking on fixed interval basis. } \\
\text { 2) Government must ensure that central \& } \\
\text { state agencies must be apprised with the } \\
\text { larger objective of the said coal projects } \\
\text { and must educate them enough to bring } \\
\text { them in alignment with larger goals of the } \\
\text { government. } \\
\text { 3) Government must map the entire coal } \\
\text { bearing land along with the family tree } \\
\text { and history of the land owners. This can } \\
\text { be done by strengthening the existing } \\
\text { system of land- banks with use of } \\
\text { digitization. The data can be then updated } \\
\text { at regular intervals and should be provided } \\
\text { to the respective project proponents at a } \\
\text { premium. This would bring in } \\
\text { transparency and speed in entire land } \\
\text { acquisition process. }\end{array}$ \\
\hline $\begin{array}{l}\text { 2. Technology } \\
\text { bottleneck }\end{array}$ & $\begin{array}{l}\text { a) Around } 45 \% \text { to } 50 \% \text { of Indian coal } \\
\text { production comes through opencast mines. } \\
\text { With stricter environmental norms, challenges } \\
\text { in obtaining surface rights for opencast } \\
\text { mining, accessing the coal under densely } \\
\text { populated regions, access to the deeper } \\
\text { deposit ( }>300 \text { meters); the need of hour is to } \\
\text { shift towards underground mining method. } \\
\text { b) Due to poor recovery percentage from } \\
\text { underground mining method the challenge is } \\
\text { to bring in mass production technologies in } \\
\text { underground coal mining along with scientific } \\
\text { studies to allow the concurrent activity of } \\
\text { mining beneath the earth surface as well as } \\
\text { alternate usage of the surface area above it. }\end{array}$ & $\begin{array}{l}\text { 1) According to Indian coal statistics, } 60 \% \\
\text { of coal resources have been established at } \\
\text { a depth of less than } 300 \text { meters. }{ }^{1} \\
\text { Government. must therefore promote } \\
\text { R\&D activities in mass production } \\
\text { technologies for underground coal mining } \\
\text { to harness the underground potential. } \\
\text { 2) Government must encourage and support } \\
\text { foreign technology infusion, especially in } \\
\text { underground coal mining methods through } \\
\text { industry-academic collaboration, setting } \\
\text { up of coal extraction technology centers } \\
\text { for R\&D, strengthening existing Indian } \\
\text { mining technology centers by providing } \\
\text { support for research facilities }\end{array}$ \\
\hline 3. Financing & $\begin{array}{l}\text { a) Due to high capital-intensive nature of the } \\
\text { coal mining business and long gestation } \\
\text { periods, the general capital structure is in the } \\
\text { range of } 70: 30 \text { (Debt: Equity) or higher, and } \\
\text { that is a cause of concern. } \\
\text { b) Along with this, the lenders are generally } \\
\text { reluctant from investing in high carbon } \\
\text { footprint businesses. }\end{array}$ & $\begin{array}{l}\text { 1) For non-fundable part of the project i.e. } \\
\text { land, R\&R, etc. the government must } \\
\text { come up with something like viability gap } \\
\text { funding (VGF) in order to share the risk } \\
\text { of investment. } \\
\text { 2) To tackle the aspect of evaluating the } \\
\text { expenses incurred by prior allottees, a } \\
\text { realistic valuation of the concerned coal } \\
\text { block asset/equipment/infrastructure }\end{array}$ \\
\hline
\end{tabular}




\begin{tabular}{|c|c|c|c|}
\hline \multirow[t]{2}{*}{ Challenges } & Key concerns & & Recommended actions \\
\hline & $\begin{array}{l}\text { c) Land, R\&R, upfront amount payment, and } \\
\text { previous allottee payments account for } \\
\text { around } 60 \% \text { of the initial capital investment } \\
\text { and is non-fundable by any of the financing } \\
\text { agencies including Non- Banking Finance } \\
\text { Companies (NBFCs)/banks. Thereby } \\
\text { achieving the timely financial closure of the } \\
\text { project always remains a challenge. } \\
\text { d) In case of allotment or re-auctioning of coal } \\
\text { blocks the valuation of existing mining } \\
\text { infrastructure remains a huge challenge. }\end{array}$ & & $\begin{array}{l}\text { created etc. must be done by } 3 \text { rd party } \\
\text { nominated by the government } / \text { mine. }\end{array}$ \\
\hline $\begin{array}{l}\text { 4. Threat of } \\
\text { alternate fuel } \\
\text { sources, } \\
\text { renewables \& } \\
\text { energy storage }\end{array}$ & $\begin{array}{l}\text { a) Government is focusing towards } \\
\text { decarbonizing all those industries which are } \\
\text { emitting high SOx, NOx and other } \\
\text { particulate matters through alternate sources } \\
\text { like Hydrogen, Carbon Capture \& } \\
\text { Underground Storage (CCUS), Solar Energy, } \\
\text { Wind Energy, Biofuels \& Biomass and } \\
\text { Waste Energy Generation. All these clean } \\
\text { energy sources are creating a mistrust against } \\
\text { the usage of dry fuel for future } \\
\text { developments and pulling away investors' } \\
\text { interests } \\
\text { b) In addition to above, energy storage has } \\
\text { become another game changer which is } \\
\text { currently not economical for industrial } \\
\text { applications but with technology } \\
\text { advancement over a decade it will be a major } \\
\text { factor for growth of renewables and wider } \\
\text { applications. }\end{array}$ & 1) & $\begin{array}{l}\text { The supply of renewables has two major } \\
\text { issues: first it has low PLF (Plant Load } \\
\text { Factor) \% ranging from } \sim 18 \% \text { to } 20 \% \text { and } \\
\text { second the intermittent supply of energy to } \\
\text { maintain the continuous flow of electricity } \\
\text { into the grid due to the vagaries of weather. } \\
\text { On the other hand coal is still the most } \\
\text { trusted source of fuel for providing an even } \\
\text { base load energy and maintaining the grid } \\
\text { frequency } \\
\text { Government of India has already introduced } \\
\text { hybrid tenders ensuring integration of renewable } \\
\text { energy ( } 51 \% \text { ) and power through coal ( } 49 \% \text { ). } \\
\text { However success of such programmes depend } \\
\text { upon adequately addressing the sourcing of coal } \\
\text { by power generation companies participating in } \\
\text { such bidding. } \\
\text { Even for energy storage to work efficiently it } \\
\text { requires minimum base load of charging. The } \\
\text { battery storage itself cannot depend upon } \\
\text { intermittent renewables supply sources and } \\
\text { hence judicious integration with sustained base } \\
\text { load of energy needs to be provided. Thus } \\
\text { government must take a holistic view about } \\
\text { coal, renewables nd energy storage. }\end{array}$ \\
\hline $\begin{array}{l}\text { 5. Non-adherence to } \\
\text { SDG (Sustainable } \\
\text { Development } \\
\text { Goals) }\end{array}$ & $\begin{array}{l}\text { a) SDGs } 13^{2} \text { (Take urgent action to combat } \\
\text { climate change and its impact) states that all } \\
\text { efforts must be done towards climate change } \\
\text { to limit the global temperature to } 1.5 \text { degree } \\
\text { Celsius by } 2050 \text {. In this regards all the old } \\
\text { generation power plants not adhering to } \\
\text { emission standards needs to be retrofitted } \\
\text { with FGDs (Flue-gas desulfurization) or else } \\
\text { will be shut down by December } 2022 \text {. This } \\
\text { comes as a major challenge towards } \\
\text { continuation ofcoal as a primary fuel source. }\end{array}$ & 1) & $\begin{array}{l}\text { Government must promulgate the mandatory } \\
\text { usage of clean thermal coal in power } \\
\text { generation. Washing of coal with advanced } \\
\text { technology close circuit coal-washer plants } \\
\text { will enhance the overall efficiency of power } \\
\text { generation and reduction in dust suppression } \\
\text { as well as ash generation. This one step will } \\
\text { help the polluting coal mining sector inching } \\
\text { closer to the SGD. } \\
\text { Indian coal sector provides employment to } \\
\text { millions of people residing in the rural areas. If } \\
\text { government doesn't give enough attention to } \\
\text { coal sector keeping in mind the SDGs then } \\
\text { there may be a huge unemployment problem } \\
\text { in the near future. Judicious balance between } \\
\text { environmental concerns and employment } \\
\text { concerns is thus needed. }\end{array}$ \\
\hline
\end{tabular}




\begin{tabular}{|c|c|c|}
\hline Challenges & Key concerns & Recommended actions \\
\hline $\begin{array}{l}\text { 6. Government } \\
\text { policy of } \\
\text { promoting a } \\
\text { natural gas based } \\
\text { economy }\end{array}$ & $\begin{array}{l}\text { a) Government intends to enhance the share of } \\
\text { gas in Indian energy basket to } 15 \% \text { from } \\
\text { current } 6 \% \text { by } 2030 \text {. This is in line with } \\
\text { setting up gas based power generation and } \\
\text { setting up an LNG import terminals in India. } \\
\text { b) Apart from this the government is giving } \\
\text { special impetus to non-conventional gas } \\
\text { sources like CBM (Coal Bed Methane), Shale } \\
\text { gas etc. With move towards setting up a gas } \\
\text { based economy (which is considered as cleaner } \\
\text { source of energy) is shifting focus away from } \\
\text { the dry fuel. }\end{array}$ & $\begin{array}{l}\text { 1) Government has already initiated the } \\
\text { promulgation of coal gasification \& } \\
\text { liquefaction programmes, which will be a } \\
\text { major thrust towards moving to gas based } \\
\text { economy. Government must promote the } \\
\text { extraction of methane trapped in the } \\
\text { abundant coal mines through infusion of } \\
\text { technology. } \\
\text { 2) Apart from this the government. Must } \\
\text { also come up with mixed tenders for the } \\
\text { coal mines where after the coal extraction } \\
\text { the rights must be given to the coal miner } \\
\text { to commercially extract \& produce the } \\
\text { gas (mainly methane) trapped in coal } \\
\text { beds. This will bring in wider investment } \\
\text { in the coal mining sector. }\end{array}$ \\
\hline
\end{tabular}

Source: Ministry of Commerce and Industry; https://commerce.gov.in/; Ministry of Coal; https://coal.nic.in/

CIL: Coal India Limited; SCCL: Singreni Collieries Company Limited; MECL: Mineral Exploration Company Limited; CMPDI: Central Mine Planning \& Development Institute; GSI: Geological Survey of India; DMF: District Mineral Foundation; NMET: National Mineral Exploration Trust; GST: Goods and Service Tax

$\mathrm{kg}$ ) is hard to avoid. With abundance of resource availability and relative ease of mining due to sedimentary nature of the bedded deposits, it has becomes the primary source of energy supply in India. Going forward with adoption of newer sources of energy like hydrogen, battery storage, nonconventional gas, renewable sources; the dry fuel has to get evolved in the decades to come. In order to decarbonize the dry fuel, the aim is to decarbonize the entire value chain of coal mining activity through which the coal is being extracted and put to use. Below here are the few areas which will aide coal to become sustainable for use:

a. Transitional shift in India's energy basket: Government of India is envisaging to increasing the share of natural gas in India's energy basket from $6 \%$ to $15 \%$. This will enhance the use of relatively clean energy (natural gas is cleaner as compared to coal) and march a step closer towards fulfilling SDG13. Gas will play a major role in decarbonizing the coal as it finds its application as a reducing agent in sectors like steel making, sponge iron making, cement sector etc. Indian companies are relentlessly working towards technology development for substituting coal as a reducing agent. Coal sector has to adapt to this shift and hence must readily adopt technologies like underground coal gasification.

b. Importance of coal washing: MOEFCC with its recent amendment in Environmental Protection Act 2020 (Amendment) has done away with the usage of coal washing. Coal washing is the integral part of the entire value chain of coal mining to coal usage in power plants. Many empirical studies have been done [20] in undermining the benefits of using washed non-coking coal in power generation. The Indian coal has an inherent nature of higher ash content and due to multiple handling of ash at generating points and disposal points pollute the environment. In order to make coal less polluting, advanced technology enabled zero discharge coal-washer plants are the need of an hour. Coal industry stakeholders of India working for sustainable coal must also work towards bringing the mandatory usage of coal washing using new technologies.

c. Replacement of diesel driven trucks with LNG: High speed diesel (HSD) is generally used to operate heavy-duty offroad trucks in coal mines. Besides the high operating cost of diesel driven trucks, it also contributes to higher $\mathrm{SO}_{\mathrm{x}}$ and $\mathrm{NO}_{x}$ pollutants. Coal mining industry players are exploring the options of replacing HSD by LNG (liquefied natural gas) in the heavy-duty trucks used for coal mining activities [21]. However other challenges associated with LNG usage like imported cost of LNG, exchange rate risk, transportation of LNG to the mining sites, setting up an LNG refueling station from the nearest LNG terminals etc. are must to be tackled. Pilot studies are being undertaken in some coal based power plants where LNG fleets are being introduced (Paliwal and Yadav, 2019).

d. Digitalization of coal mining: With Industry 4.0 revolution, human and machines are coming together forming a symbiotic relationship that enhances the operational excellence and process improvement. Technologies like drones, block chain, machine learning, artificial intelligence coupled with IoT platforms are changing the landscape of coal mining industry across the world. Right from mine survey and planning, fleet management, drilling and blasting, combined heat and power (CHP) and coal-washer plant maintenance, to monitoring health, safety and hazards 
the mining players are integrating it and enhancing the overall mining business operations. Therefore, promulgating digitalization is must for the coal mining industry; as for highly mechanized mines (both opencast and underground) monitoring the emissions, controlling the operations and enhancing the overall efficiency is must to promote sustainable clean coal mining.

e. Contribution of coal in India's GDP: Coal is going to remain one of the key 8 indicators for core sector growth in India. Indian government is taking all steps to make coal sector self-dependent by promoting the domestic coal exploitation. Coal contributes to the nation's growth through generation of sovereign wealth for government along with creation of direct and indirect employment to millions of people. Thus, it becomes imperative to provide undivided attention to the huge challenges faced by coal sector by aligning it with SDG13 goals made under COP 21 convention of UNFCCC [22].

f. Immediate actions required: Government must channelize its communication towards coal mining sector; wherein it must focus towards promoting R\&D for usage of clean coal technology, enhancing investment through innovative financial products, reinforcing policy focused on decarbonization of coal mining operations; and educating the masses towards generating the awareness. All this should be done through conducting roadshows, holding workshops for project affected people, creating vocational courses for employment generation etc.

Source: Ministry of Commerce and Industry; https:// commerce.gov.in/; Ministry of Coal; https://coal.nic.in/ MOEFCC: Ministry of Environment, Forest \& Climate Change; LNG: Liquefied Natural Gas, OC: Opencast; UG: Underground; IoT: Internet of things; SDG: Sustainable Development Goals; COP: Conference of the Parties; UNFCCC: United Nations Framework Convention on Climate Change

\subsection{Making Indian coal sustainable: Role of Industry 4.0}

Industrial revolution over the years has been slowly adopted in the coal mining process be it use of steam engines for coal haulage, mass production technologies for rapid capacity throughput and use of computers for automation of efficient mining system. With the advent of Industry 4.0 it envisages to use human-machine interaction in coal mining activities. This will bring in the paradigm shift in entire coal mining activity through sustainability in mine operations, mine safety, manpower utilization, cost optimization and process improvement. With underground mining as future of Indian coal mining the adoption of Industry 4.0 will be of paramount importance, also from the perspective of safety of man and machines higher recovery rate and mass production.

In the Indian context the coal mining players especially the coal mining contractors are yet to understand the benefit of digitalization and its overall impact on sustainable coal mining operations. The probable reasons could with high upfront costs (capital expenditure) of digitalization, recurring annual licensing cost, and resistance towards adaptability of digital intervention in coal mining including lack of training and awareness for Industry 4.0.

Table 4 are the suggested digital interventions as per prevailing industry practices for sustainable coal mining activities.

\subsection{Discussion, managerial implications and conclusion}

The analysis produced important recommendations for the Indian Government, who is the sovereign owner of coal mine acreage in India. Government needs to expedite the process of transferring the coal mine area surface rights to the successful bidders along with proactive facilitation of granting them all relevant clearances. Necessary mechanism to monitoring of progress on the entire award process is the key to execution. This also leads to the realization of the goal of ease of doing business. Wherever needed state level stakeholders should be educated by the government about the role, coal industry plays in economic and human development so that the sector operates with least of friction and goal-conflict. Similarly the goal of maximizing revenue during coal-mine auction process should be balanced with resultant escalation of cost for end-users. Lifecycle costs are essential keeping the larger picture in mind. Financial instruments like viability gap funding (VGF) and transparent objective valuation of coal mining assets by the government is key to support the successful bidders' financial management. Government needs to give a big push to modernizing coal supply chain including transportation and allied infrastructure. Similarly technology should be used to digitize coal mining block records for transparency and better accessibility. Intensive application of digitalization and Industry 4.0 are important to achieve these. Government also needs to relook at the lenient coal-washing policy to address the serious concerns the experts have raised about such a policy impact on the environment. The potential of underground coal mining including underground coal gasification is incontestable. Moreover it not only brings in efficiency but also aligns with the goal of making Indian coal sector sustainable. Government should allocate funding for research and development and work closely with national and international academic, research and consulting organizations towards this.

\subsection{OTHER MAJOR CONTEXTUAL POLICY ISSUES}

(a) Pros and cons of only coal-based policy $v /$ s hybrid policy of coal and renewable utilization including responsible and environmentally sustainable mining

Ministry of New \& Renewable Energy (MNRE) and Ministry of Coal (MoC) has in collaboration come up with hybrid tenders whereas the share of coal in hybrid power generation $49 \%$ while for renewables it is $51 \%$ [23]. The tenders received no response as it misses out on the fuel 
Table 4: Application of Industry 4.0 In COAL IndUStry

\begin{tabular}{|c|c|c|c|}
\hline & Mining Processes & Industry 4.0 Intervention & Impact \\
\hline 1 & $\begin{array}{l}\text { Mine survey and } \\
\text { planning }\end{array}$ & $\begin{array}{l}\text { Aerial survey through drones, monitoring } \\
\text { and control through Internet of things (IoT) } \\
\text { device; 3D mapping of excavation enabling } \\
\text { real time monitoring of daily mine progress. }\end{array}$ & $\begin{array}{l}\text { Better supervision of inaccessible region of mine } \\
\text { area, forest cover area, mine boundary } \\
\text { demarcation to avoid illegal mining (beyond mine } \\
\text { lease); Quality control through identification of } \\
\text { low quality and high-quality coal zones. }\end{array}$ \\
\hline 2 & Drilling and blasting & $\begin{array}{l}\text { Usage of GPS (Global Positioning Systems) } \\
\text { guided precision drills with IoT device and } \\
\text { blasting simulation tools. }\end{array}$ & $\begin{array}{l}\text { Efficient drilling activity along with blasting } \\
\text { optimization results in cost savings in usage of } \\
\text { explosive and better fragmentation. }\end{array}$ \\
\hline 3 & Load haul dump & $\begin{array}{l}\text { Use of fleet management tool (based on the } \\
\text { technique of linear programming). }\end{array}$ & $\begin{array}{l}\text { Improved availability of equipment, efficient } \\
\text { utilization and proper equipment planning. }\end{array}$ \\
\hline 4 & $\begin{array}{l}\text { Coal handling and } \\
\text { washing and stockpiling }\end{array}$ & $\begin{array}{l}\text { Supervisory control and data acquisition } \\
\text { (SCADA) system with programmable logic } \\
\text { controller (PLC); Drone based stockpile } \\
\text { monitoring; Laboratory information } \\
\text { management system (LIMS). }\end{array}$ & $\begin{array}{l}\text { Seamless plant management with reduced and } \\
\text { controlled plant shutdown; improved plant } \\
\text { availability and sampling for quality check. }\end{array}$ \\
\hline 5 & $\begin{array}{l}\text { Coal transportation to } \\
\text { end user }\end{array}$ & $\begin{array}{l}\text { GPS enabled coal tracking for loading, use of } \\
\text { blockchain for finished coal movement and } \\
\text { transfer. }\end{array}$ & $\begin{array}{l}\text { Monitoring of coal transportation from mine to } \\
\text { end user with supply side management \& } \\
\text { tracking. }\end{array}$ \\
\hline
\end{tabular}

sourcing (i.e., coal allocation) for thermal power generation [24]. Another major issue the sector is grappling while integrating the hybrid energy is non-availability of transmission infrastructure for hybrid power generation. On the other hand, coal mining PSUs (like CIL, NTPC, Neyveli Lignite) are diversifying their business portfolio by foraying into renewables for environmentally sustainable mining few measures needed are digitalization of mining operations, washing of coal, star-rating of coal mines, mechanization of mines along with robust coal evacuation infrastructure like railway sidings, slurry pipelines, pipe/belt conveyors etc.

\section{(b) Coal chemicals}

India is at a fledging stage regarding coal to chemicals technology. In year $2020 \mathrm{MoC}$ has notified the use of commercially mined coal for liquefaction purpose and its usage will be incentivized subsequently [25]. Going ahead in order to reduce import bill for crude oil government is planning to use coal to chemicals but it will require policy initiatives like no end- user discrimination, priority usage, tax rebate, technology infusion and financial support.

\section{(c) Performance of the old and existing policies leading to responsible privatization of Indian coal sector}

As discussed in previous sections, 100\% FDI in Indian coal mining exploration and exploitation has been allowed since 2003 [26]. This has encouraged private participation in Indian coal mining sector. Since then, the private participation in coal mining is allowed through joint ventures (JV model) wherein Indian government and private entities have participated through 50:50 equity partnerships. This has unfortunately resulted in collusion of coal blocks' allocation. Further to this the honorable Supreme Court verdict in August 2014, has quashed the allotment of 204 coal blocks as well as repealed the JV model of participation. Subsequently major reforms took place in Indian coal mining sector through amendments in MMDR 2015 Act, introduction of Coal Mines (Special Provision) Act 2015, and Mineral auction Rules 2015 wherein introduction of auction methodology through transparent bidding were introduced. Post 2015 responsible privatization has commenced in coal mining sector through Mine Developer \& Operator (MDO) route and commercial coal auctions.

\section{(d) Coal mining education and employment policy to cater to the emerging needs}

Mining education in India has been mostly offered by institutions of repute like IITs, NITs, and other Government colleges. With influx of technology and investments in mining sector there is a paradigm shift in requirement of skilled resources. There is a need for skill development programmes across all the functionalities in mining sector like IT integration in mining, complete mechanization of mines, deployment of advanced mining techniques, mine planning, project financing, and operations management in mines, operator's training for both underground and opencast equipment and vocational training for semiskilled and unskilled manpower in mines. With privatization across the Indian mining sector employment policy must ensure skilled based hiring and safe working environment in adherence to 
all the statuary compliances. Alongside this there is a need for standardization of wages for working manpower (skilled, unskilled and semiskilled) in accordance with the highpowered committee.

(e) Juxtaposing Indian coal mining policies with salient coal mining practices with Australia, South Africa and the USA

The effective tax rate is the highest in Indian coal mining sector at approximate $60 \%$ as compared to coal producing nations like Australia, Indonesia, USA and South Africa. Due to high effective tax rate, coal mining business has narrow margins. Countries like Australia, USA and South Africa are heavily dependent on use of technology; be it mass production techniques for underground coal mining or use of Industry 4.0 of mining operations. On the contrary, Indian coal mining practices have completely turned into outsourcing model where a Mine Developer \& Operator (MDO) gets appointed for a fixed fee and scientific mining becomes difficult to achieve. In South Africa, the government supports various level of operations by the mining companies. To improve the safety measures by mining industry, the "Leon Commission of Inquiry into Safety and Health in Mining Industry" made several recommendations which later on paved the way for enactment of the Mine Health and Safety Act of 1996, the Occupational Diseases in Mines and Works Act, 1973 and the Compensation for Occupational Injuries and Diseases Act, 1993 [27]. Australia has a reserve of major minerals and therefore supports mining activities. The Australian legislations majorly focus on the health and safety during mining operations and having the provisions relating to the "Health and Safety Representatives (HSRs), compensation provisions for fatal and non-fatal injuries etc [28].

In U.S, the "Mine Safety and Health Administration (MSHA)" is entrusted the powers to develop and enforce the mining regulations and the "National Institute for Occupational Safety and Health (NIOSH)" is involved in the research and training programme for the mines relating health problems [29].

Despite all skepticism, coal plays a major role to complement government and policy makers' renewable energy push including energy storage systems. Thus it is important to bring all energy industry stakeholders on the same page and continue usage of coal in efficient ways towards creating a wider energy system. Indian coal sector provides employment to millions of people, especially those residing in the rural areas and belonging to poor strata of society. Therefore it is important for the government to give an adequate attention to coal sector keeping the sustainable development of the sector in mind, without which not only the livelihood of millions of people will be at stake but the country may be put to short to medium term energy-security shocks. An efficient, transparent and sustainable coal sector is crucial for Indian energy sector, economy and society.

\section{References}

1. Alasdair Monk (2018). How IIoT Is Changing Mining. Available on: https://www.industryweek.com/technologyand- iiot/article/22026902/how-iiot-is-changing-mining

2. Antwi, E.K., Owusu-Banahene, W., Boakye-Danquah, J. et al. (2017): Sustainability assessment of mine-affected communities in Ghana: towards ecosystems and livelihood restoration. Sustain Sci 12, 747-767. https:// doi.org/10.1007/s11625-017-0474-9

3. Benton, Dale (2019): Industry 4.0 and mining: keeping technology at the heart of the matter. Mining Global Magazine. September 2019. Available on: https:// www.miningglobal.com/digital-mining/industry-40-andmining-keeping-technology-heart-matter

4. Bertayeva, Kulyash and Panaedova, Galina and Natocheeva, Natalia and Kulagovskaya, Tat'yana and Belyanchikova, Tatiana. (2019). Industry 4.0 in the mining industry: global trends and innovative development. E3S Web of Conferences. 135. 04026. 10.1051/e3sconf/ 201913504026.

5. Bhatnagar, Molshree. (2014): Competition and Regulatory Issues in Coal Sector in India, CIRC Working Paper No.11. New Delhi: CUTS Institute for Regulation \& Competition. Available on https://circ.in/working-paper-11/

6. Carl, J. (2015): The causes and implications of India's coal production shortfall. In M. Thurber \& R. Morse (Eds.), The Global Coal Market: Supplying the Major Fuel for Emerging Economies (pp.123-163). Cambridge: Cambridge University Press. doi:10.1017/ CBO9781316136058.004

7. Chattopadhyay S., Chattopadhyay D. (2020): Coal and Other Mining Operations: Role of Sustainability. In: Malhotra R. (eds) Fossil Energy. Encyclopedia of Sustainability Science and Technology Series. Springer, New York, NY. https:// doi.org/10.1007/978-1-4939-9763-3_864

8. Dermot J. Roddy and Paul L. Younger (2010): Underground coal gasification with CCS: a pathway to decarbonising industry. Energy Environ. Sci., 2010, 3, 400-407

9. Dorota Burchart-Korol, Piotr Krawczyk Krystyna Czaplicka-Kolarz MarianTurek and Wojciech Borkowski (2014): Development of Sustainability Assessment Method of Coal Mines. Journal of Sustainable Mining. Volume 13, Issue 4, 2014, P.5-11

10. Dorota Palka and Tamer Rizaoglu. (2019): The concept of hard coal mine in the perspective of Industry 4.0.

11. MAPE 2019, volume 2, issue 1, pp. 327-335.

12. Evans, R. et al. (2003): Water Use and Sustainable Development in Coal Mining: A case study from Central Queensland. Sustainable Development Conference, MCA, Brisbane.

13. Frewer L J, Fischer A R H, Wentholt M T A, Marvin H J $\mathrm{P}$, et al. 'The use of Delphi methodology in agrifood policy development: Some lessons learned', Technological Forecasting and Social Change, 2011, vol.78, pg. (1514-25) 4, Pg.332-343, https://doi.org/10.1093/scipol/sct062

14. https://academic.oup.com/spp/article/41/3/332/1632782 
15. Huang, J., Tian, C., Xing, L., Bian, Z., \& Miao, X. (2017): Green and Sustainable Mining: Underground Coal Mine Fully Mechanized Solid Dense Stowing-Mining Method. Sustainability, 9(8), 1418. doi:10.3390/su9081418

16. Hugh Durrant-Whyte, Ryan Geraghty, Ferran Pujol, and Richard Sellschop (2015): How digital innovation can improve mining productivity. McKinsey \& Company. Available on: https://www.mckinsey.com/industries/ metals-and-mining/our-insights/how-digital-innovationcan-improve-mining-productivity

17. IAEA-TECDOC-1244. (1998): Impact of new environmental and safety regulations on uranium exploration, mining, milling and management of its waste Proceedings of a Technical Committee meeting held in Vienna, 14-17 September 1998. As available on: https://wwwpub.iaea.org/MTCD/Publications/PDF/te_1244_prn.pdf

18. Ioan Batrancea, Larissa Batrancea, Anca Nichita, Lucian Gaban, Ema Masca, Ioan-Dan Morar, Gheorghe Fatacean and Andrei Moscviciov (2019): An econometric approach on production, costs and profit in Romanian coal mining enterprises, Economic Research-Ekonomska Istra•ivanja, 32:1, $1019-1036$, DOI: 10.1080/ 1331677X.2019.1595080

19. John P. Banks, Tim Boersma, and Charles K. Ebinger (2015). Does decarbonization mean de-coalification? Discussing carbon reduction policies. Brookings, USA. As available on: https:/www.brookings.edu/articles/ does-decarbonization-mean-de-coalification-discussingcarbon-reduction-policies.

20. Katz, Rebecca \& Gornto, Sarah \& Chretien, Jean. (2011): Expert Opinion on Implementation Strategies for the International Health Regulations (2005). World Medical \& Health Policy. 3. 10.2202/1948-4682.1178.

21. Kirk, Thomas and Jessie Lund (2018): Decarbonization Pathways for Mines: A Headlamp in the Darkness. Rocky Mountain Institute, 2018. https://info.rmi.org/ pathways_for_mines/. Available on: https://rmi.org/wpcontent/uploads/2018/08/RMI_Decarbonization_ Pathways_for_Mines_2018.pdf

22. Konstantin Löffler, Karlo Hainsch, Thorsten Burandt, Pao-Yu Oei, and Christian von Hirschhausen (2017): Decarbonizing the Indian Energy System until 2050: An Application of the Open Source Energy Modeling System OSeMOSYS. IAEE Energy Forum. Singapore issue 2017.

23. Kulshreshtha, Mudit \& Parikh, Jyoti. (2001): A study of productivity in the Indian coal sector. Energy Policy. 29. 701-713. 10.1016/S0301-4215(01)00003-9.

24. Lahiri-Dutt, Kuntala. (2007): Coal mining industry at the crossroads: Towards a Coal policy for liberalising India. Australian National University, Australia South Asia Research Centre, ASARC Working Papers.

25. Lahiry, Samar (2017): Can mining be sustainable? Down to Earth. 25 $5^{\text {th }}$ April 2017. Available on: https:// www.downtoearth.org.in/blog/mining/can-mining-besustainable 57683

26. Lindsay Delevingne, Will Glazener, Liesbet Grégoir, and
Kimberly Henderson (2020): Climate risk and decarbonization: What every mining CEO needs to know? McKinsey \& Company. Available on: https:// www.mckinsey.com/business-functions/sustainability/ our-insights/climate-risk-and-decarbonization-whatevery-mining-ceo-needs-to-know.

27. Mining Review Africa (2019): Industry 4.0 is electrifying the mining industry. Available on:https:// www.miningreview.com/health-and-safety/industry-4-0is-electrifying-the-mining-industry/

28. O'Brien, John and Biggs, Tim (2020): Trend 5: The path to decarbonization: Miners' role in reducing emissions. Deloitte. As available on: https:/www2.deloitte.com/us/ en/insights/industry/mining-and-metals/tracking-thetrends/2020/path-to-decarbonization-minings-role-inclimate-change.html

29. OCE-Office of the Chief Economist, Australian Government, Department of Industry, Innovation and Science; Report: Coal in India 2019; Available on: https:// www.industry.gov.au/sites/default/files/2019-08/coal-inindia-2019-report.pdf

30. Paliwal, Pramod \& Yadav, Sudhir .2019. Natural Gas Transmission and Distribution Business. CRC Press. ISBN: 978-1-136-59830-0

31. Pavloudakis, Francis and Roumpos, Christos and Evangelos, Karlopoulos and Koukouzas, Nikolaos and Sachanidis, Chariton and Spyridon, Pyrtses. (2019): Economic And Social Impact Assessment Of Decarbonisation In Ptolemais Lignite Mining Area.

32. Qian, M.-G. (2010): On sustainable coal mining in China. Meitan Xuebao/Journal of the China Coal Society. 35. 529-534.

33. Sarah Hilton (2019): Mining giant BHP goes digital in race for survival. Nikkei Asian Review. February 15, 2019. Available on: https://asia.nikkei.com/Business/Companyin-focus/Mining-giant-BHP-goes-digital-in-race-forsurvival

34. Sean Carter (2017): Industry 4.0 in the mining sector. Available on: https://www.processonline.com.au/ content/industrial-networks-buses/article/industry-4-0in-the-mining-sector-1259053519

35. Sharma, Ashish, A Study of Coal Mines in India (2012): Available on SSRN: https://ssrn.com/abstract= 2047437

36. Spencer, Thomas et al. (2018): "Coal Transition in India", TERI Discussion Paper (New Delhi: The Energy and Resources Institute).

37. Tongia \& Gross (2019): "Coal in India-Adjusting to transition" Brookings Institution, India. Available on https://www.brookings.edu/wp-content/uploads/2019/ 03/fp_20190731_coal_in_india.pdf

38. Tongia, Rahul (2020). Why India's push for private-sector coal mining won't raise carbon emissions. Brookings, India. Available on: https://www.brookings.edu/blog/ planetpolicy/2020/07/20/why-indias-push-for-privatesector-coal-mining-wont-raise-carbon-emissions.

(Continued on page 52) 